\title{
State and Legal Policy for the Protection of Children in the Digital Environment
}

\author{
Yuliia Hradova *[0000-0002-2794-6272], Oleksandr Zhytnyi [0000-0003-0795-626X], \\ Sergei Tereshchuk [0000-0002-7263-4155] \\ V.N. Karazin Kharkiv National University, Ukraine \\ *julia.gradova@karazin.ua
}

\begin{abstract}
Digital technology and the Internet have made our lives much easier by providing opportunities to work, study, and shop online. Today half of humanity uses the Internet and social networks, which have brought risks and dangers despite significant benefits. In the digital environment the most vulnerable category of population are children, who may be victims of cyber-violence, especially cyberbullying or sexting According to the results of an anonymous survey among students, we were able to find out that $54 \%$ of respondents had faced cyberbullying. As for sexting, about $50 \%$ of interviwed had received an offer to send their intimate photo / video, but only $20 \%$ of them agreed. During our research we tried to find out the reasons for the growth of cyberbullying in the digital environment, as well as ways to counter online harassment. According to the respondents, criminalization of counteracting cyberbullying and sexting, as well as proper state policy should be the most effective method. It should include the development of relevant regulations, various campaigns to protect children from cyberbullying, the creation of hotlines for victims of cyberbullying and so on. The public authority which is responsible for developing of the children's digital rights and ensuring their safety in the digital environment is the Ministry of Digital Transformation. It has proposed the Concept for the Development of Digital Rights of Children, which provides with the implementation of many measures to protect children`s rights in the digital environment, including the criminalization of cybergrooming.
\end{abstract}

Keywords: cyberbullying, cybergrooming, cybercrime, sexting, digital environment, digital rights.

\section{INTRODUCTION}

We live in the time of digital technology that is deeply ingrained in our daily lives. Today it is difficult to imagine at least one day without a smartphone and the Internet. In Global Overview Report "Digital Technologies 2021" it was told that the number of people around the world using the Internet had grown to 4.66 billion and the number of social network users to 4.20 billion. It should be mentioned that the average Internet users now spends 6 hours and 54 minutes online each day. Supposing that the average person sleeps for 7 or 8 hours a day, it means that we now spend approximately 42 percent of our wake state online and that we spend almost as much time using the Internet as we sleep [1].

Humanity has received a large number of benefits through digital technology, which has greatly facilitated life. By using the Internet we can find any information, we can study and work, shop without leaving home. Despite these benefits, the Internet carries risks and dangers that often affect children and young people. The digital environment may open new ways to perpetrate violence against children. Open access to the Internet, difficulties in tracking the abuser, fear of parents' reaction to cyberthreats [2-3] and, as a result, the concealment of cyberbullying [4-5] make the child easy prey. Crises, such as pandemics, may lead to an increased risk of online harm, considering that children spend more time on virtual platforms [6].

Recommendation CM/Rec(2018)7 of the Committee of Ministers to member States on Guidelines to respect, protect and fulfil the rights of the child in the digital environment emphasizes a number of areas concern for children's healthy development and well-being which may arise in connection with the digital environment, in particular: sexual exploitation and abuse, grooming; the depiction and praise of violence and self-harm, in particular suicides; bullying, stalking and other forms of harassment, non-consensual dissemination of sexual images, extortion, hate speech, hacking, gambling; excessive use, sleep deprivation and physical harm [7]. 
In one American study it was noted that adolescents who spent more time on electronic communication and screens (e.g., social media, the Internet) and less time on nonscreen activities (e.g., in-person social interaction, sports, homework) had lower psychological wellbeing [8]. Moreover, the Internet threatens to fall victim to cyber-violence, for example - cyberbullying, which is one of the form of it. Cyberbullying can be defined as an aggressive, intentional act carried out by a group or individual, using electronic forms of contact, repeatedly and over time against a victim who cannot easily defend him or herself [9]. J. Patchin and S. Hinduja provide a similar definition of cyberbullying as deliberate and repeated harm inflicted through the use of computers, cell phones or other electronic devices [10]. The most famous classification of cyberbullying was given by N. Willard, who singled out the following varieties: flaming, harassment, denigration, impersonation, outing and trickery, exclusion, cyberstalking [11]. R. Kowalski et al. added more forms of cyberbullying: happy slapping and hopping, and also sexsting [12]. Sexting is the exchange of provocative or outright sexual content, such as text messages, photos and / or videos via smartphones, the Internet and / or social networks [13]. Although some researchers consider sexting to be a form of cyberbullying, other disagree, noting that sexting and cyberbullying are not related, sexting can be used by the aggressor to provoke further acts of cyberbullying [14]. Our research focuses on these types of cyber threats that children may face in the digital environment.

According to a study conducted by the United Nations Children's Fund (UNICEF) in 2018, among 1017-year-old Ukrainians, every fifth teenager admits being a victim of online bullying. The bad thing about cyberbullying is that it can happen anywhere and anytime. The Internet, phones, etc. operate 24 hours a day, 7 days a week. Technologies, such as computers, smartphones, and tracking devices, allow abusers to overcome geographic and spatial boundaries that would have otherwise prevented them from contacting their victims [15]. What is more, in 2020 the impact of COVID-19 hasincreased individuals' digital presence and it isspeculated that the pandemic hastriggered a significant rise in cyberbullying [16].

Overall, cyberbullying is a reflection of the culture we live in. It is now acceptable to criticize each other in any form, and the easiest way to do it is online. Noone thinks that an insulting comment left under a post on Facebook, under a photo on Instagram, or a video on Tik-Tok can be perceived as very painful and have negative consequences. Now it has become fashionable to be a hater, to try to find the most vulnerable place in the victim and hit the hardest. Unfortunately, this is what young people perceive, what they enjoy and what they want to follow. As the problem of cyberbullying has become global, the fight against cyber-violence must reach national and international levels.

\section{METHODOLOGY}

In the course of our research, we conducted an anonymous survey of students aged 17 to 22 regarding their participation in cyberbullying and sexting as victims / aggressors. 144 students of the Faculty of Law of V.N. Karazin Kharkiv National University took part in the online survey: $58 \%$ were girls, $42 \%$ were boys. We asked two blocks of questions, the first block was about cyberbullying: if students encountered this phenomenon, what types of cyberbullying they faced, how they felt at that moment, what could help in counteracting cyberbullying; the second block of questions concerned sexting, namely the experience of respondents in the exchange of sexual content.

The analysis of the survey showed a fairly high level of awareness among students, what is cyberbullying $95.7 \%$ answered positively to this question. At the same time, 57\% knew about cyberbullying from their own experience, as they had encountered its manifestations in the digital environment. A slightly different picture is observed in the results of the second block, namely the awareness of what is "sexting" - only $52.5 \%$ answered thay they knew about it, $25.5 \%$ did not know what sexting is, and another $22 \%$ heard about it, but did not remember. This situation suggests the need for outreach among young people to understand and prevent sexting and its negative consequences in the digital environment.

\section{RESEARCH RESULTS}

The results of the study showed a fairly high level of cyberbullying among young people, $57 \%$ at least once in their life faced negative comments / ridicule / threats on the Internet addressed to them. At the same time, they also acted in the role of cyberbully (aggressor), humiliating others on the Internet, social networks, groups Telegram, Viber: $14.1 \%$ did it more than once, $27.5 \%$ - once or twice. It should be noted that in the survey, even anonymous, people are more willing to take on the role of victim and less likely to admit that they committed cyberbullying by themselves.

In the digital environment respondents encountered such types of cyberbullying as: trolling $-21.4 \%$, flaming $-19.6 \%$, anonymous threats $-10.7 \%$, use of personal information $-5 \%$, exclusion $-4.3 \%$, harassment $-4.3 \%$, impersonation $-3.6 \%$, online grooming / sexting $-2.1 \%$, cyberstalking $-0.7 \%$.

Answering the question "How did you feel when faced cyberbullying?", $43.5 \%$ noted indifference, this is the correct reaction to provocations, ridicule and negative comments. If aggressor doesn`t feel any reaction to his actions, he ceases to be interested in the victim and switches to another one. Any reaction to cyberbullying encourages the aggressor to take new action, so in such situations it is necessary to ignore cyber-attacks or ban the aggressor, but in no case enter a discussion with him. 
$22.1 \%$ of respondents said that they felt irritated, $9.9 \%-$ helplessness, $9.9 \%$ - anger, $4.6 \%$ - the desire for revenge. Cyberbullying negatively affects the psychological health of adolescents, causing depression, decreased self-esteem and suicidal thoughts [17].

In the survey, we tried to find out the reasons for the growth of cyberbullying in society. Respondents singled out the following: it is difficult to prosecute for online violence $(46.4 \%)$; anonymity - you can write negative comments, insults and the victim will not know who they came from $(18.1 \%)$; the growing use of digital technologies has negative consequences in the form of cybercrime (11.6\%); it has become fashionable to be a hater $(10.9 \%)$; this is one of the ways of communication $(8 \%)$. In addition, their own options were mentioned as: mental disorders in people, dissatisfaction with life, a way of self-exaltation, proper attention to adolescents.

The last issue of the first block was devoted to combating cyberbullying, namely what can help to solve this problem. The largest percentage of respondents $(35.2 \%)$ believe that establishing criminal / administrative liability for cyberbullying is the most effective method in combating violence in the digital environment. $21.8 \%$ believe that government programs to protect children on the Internet (various chatbots, videos, posters, hotlines, where you can call if you became a victim of online violence) can help to solve this issue. The next method in combating bullying is blocking the cyber-aggressor site / platform by administrator (19\%), teaching children how to behave in case of online threats $(18.3 \%$ ). But parental control (contact tracking, correspondence), according to students, is not an effective method of combating cyberbullying - only $1.4 \%$ chose this option.

The second block of questions concerned such phenomenon as "sexting". $48.9 \%$ of respondents received requests to send sexual content, while $20.6 \%$ of them exchanged photos / videos of an intimate nature. This indicates that in most cases they rejected such a request. At the same time, $15.6 \%$ of respondents asked someone to send a photo / video of an intimate nature. While exchanging sexual content, only $22.6 \%$ were afraid that it would be spread among their circle of acquaintances or on the Internet, $13.9 \%$ did not think about the consequences, and $63.5 \%$ were not afraid at all. This figure makes you wonder that young people do not see the negative consequences of sexting and do not worry that intimate content can be used against them through blackmail, threats, distribution of photos / videos among acquaintances or on the Internet.

\section{DISCUSSION OF RESULTS}

Among the outcomes, we would like to focus on some provisions: firstly, the reason for the growth of cyberbullying in society the majority of respondents $(46.8 \%)$ named this reason as the severity of prosecution for online violence. It should be noted that all the respondents are students of the Faculty of Law, and therefore they look at the problem from a legal point of view. Nevertheless, this reason is really one of those that allows bullies to commit harassment with impunity in the digital environment. It is difficult to track the aggressor, find out his identity, establish the fact of bullying and ultimately bring him to justice. But in Ukraine the implementation of state policy in the field of countering cybercrime is dealt with by the cyber police. In addition, a victim to cyberbullying can call the hotline of the Ukrainian Helsinki Human Rights Union or the National Children's Hotline. Also it is possible to contact the Ukrainian Parliament Commissioner for Human Rights or the Educational Ombudsman Service. So, there is an opportunity to get psychological and legal assistance in the case of cybercrime, but bringing the aggressor to justice still remains problematic.

The second point of the study which we would like to notice is the counteraction to cyberbullying, namely, what can help in solving this problem. And here we have a similar position of the respondents as in the previous question. In their opinion, the establishment of criminal / administrative responsibility for cyberbullying is the most effective method in countering bullying (35.2\%). It should be noted that the current legislation provides for administrative liability for bullying (harassment), that is, acts of participants in the educational process, which consist in psychological, physical, economic, sexual violence, including the use of electronic communications against minors or juvenile or by such a person in relation to other participants of the educational process, as a result of which the mental or physical health of the victim could or has been harmed [18]. The Criminal Code of Ukraine does not provide for liability for cyberbullying, in some cases of cruelty to a person, blackmail, systematic humiliation of his human dignity or systematic unlawful compulsion to actions that contradict his will, inducement to commit suicide can be qualified as force handing a person to suicide or to attempt to suicide [19]. For offenses related to cyber grooming and sexting, the national legislation does not directly contain provisions to protect children from sexual exploitation and sexual abuse committed online. Such actions can be qualified under Article 301 of the Criminal Code of Ukraine regarding the production, storage and distribution of pornography.

In countering cyberbullying, an important place is given to state programs to protect children on the Internet: $21.8 \%$ of respondents believe that it is the state that should solve this problem by developing and using various educational programs, videos, chat bots, hotlines. Today, the Ministry of Digital Transformation of Ukraine is actively introducing activities to protect children in the digital environment. 
To solve the problem of the insufficient level of development of digital rights of the child, the Ministry of Digital Transformation of Ukraine has established a Concept for the Development of Digital Rights of Children (The Concept). It provides for the implementation of many measures to protect the children rights in the digital environment, particulary: analysis of the regulatory framework and educational programs for children, parents and teachers, determination of their level of education about modern risks in the digital environment; launching mechanisms for reporting and responding to content and services in the digital environment that contain sexual exploitation and abuse of children (SEAC) or threaten the rights of the child; information campaign to raise public awareness; improvement of regulatory legal acts; implementation and adaptation of leading technical solutions for the investigation and prevention of crimes committed in the digital environment, in which children are victims; introduction of educational programs for teachers; introduction to educational institutions of teaching digital security and media literacy; the introduction of a system for filtering content and services on the Internet in the places of learning and daily stay of the child; interviewing law enforcement officers, collecting statistical data, monitoring court decisions in the field of crimes committed against children in the digital environment, etc.

The Concept provides for the introduction and improvement of legislation on liability for crimes committed in the digital environment, particulary: it is proposed to amend the criminal legislation, according to which the liability for cyber grooming is provided, for knowingly gaining access to materials depicting SEAC and storing such materials without the purpose of distribution.

According to the National Strategy on Human Rights, ensuring the rights of the child is one of the important strategic directions, within the framework of which the mechanism for ensuring the children's safety in the digital environment should be improved [20]. Another document in the field of protecting the children's rights of children affected by delinquency is the National Strategy for Reforming the Justice System for Children for the period up to 2023. It is aimed at solving the main systemic problems of justice in relation to children, overcoming gaps in the system of interdepartmental cooperation, ensuring preventive, social and educational work and work aimed at resocialization of minors prone to illegal behavior and committed offenses, as well as strengthening the protection of children's rights who have suffered from offenses, including those of a violent nature, and children who are witnesses of offenses [21].

The state social program "National Action Plan for the Implementation of the UN Convention on the Rights of the Child" for the period up to 2021 in the framework of ensuring the protection of children from violence provides for: the formation of a policy of public intolerance to all forms of violence against children in society; protection of children from exploitation, sexual abuse; intensifying awareness-raising work to prevent all forms of violence against children. As part of creating a safe information space for children, it is envisaged to ensure the protection of the child's personal data and other confidential information about him, to ensure the safety of children in the information space; formation of a policy to prevent manifestations of radicalism, racism, xenophobia and other forms of extremism of children; introduction of a system of social and pedagogical work with parents on child safety in the information space [22].

General Comment 25 (2021) on children's rights in relation to the digital environment notes that "States should take legislative and administrative measures to protect children from violence in the digital environment" [6]. This includes regular review and updating of legislation to protect children from all forms of violence in the digital environment.

\section{CONCLUSIONS}

Ukraine has ratified a number of international legal documents related to the protection of children, including the digital environment. Particulary, the Convention on the Rights of the Child, the Council of Europe Convention on the Protection of Children against Sexual Exploitation and Sexual Abuse, the Convention on the Rights of the Child on the Sale of Children, Child Prostitution and Child Pornography and its Optional Protocol, the Convention on Cybercrime. The provisions of these documents are implemented in national legislation, which aims to protect children from cyber violence.

The state body responsible for the development of children's digital rights and ensuring their safety in the digital environment is the Ministry of Digital Transformation of Ukraine. Within the framework of the ministerial project "Child Safety on the Internet", which should protect children online from harmful materials, cyberbullying, suicidal Internet unions, sexual violence, etc., an information and educational campaign is being carried out, chatbots are being created to counter cyberbullying and sexting, recommendations for the protection of children in the digital environment are being developed. Public organizations are actively involved in this work, thanks to which the All-Ukrainian campaign against cyberbullying Docudays UA was founded, documentary animated videos about cyberbullying were shot, a week against bullying was held, which was attended by more than three hundred schools, information materials for children and parents about the phenomenon of cyberbullying were developed. Such activities contribute to the protection of children's rights in the digital environment and help to prevent cyber violence. 


\section{REFERENCES}

[1] Kemp, S. (2021), Digital 2021: Global Overview Report, 27 january, available at: https://datareportal.com/reports/digital-2021global-overview-report

[2] Tolubko, Volodymyr Vyshnivskyi, Viktor Mukhin, Vadym Haidur, Halyna Dovzhenko, Nadiia Ilin, Oleh and Vasylenko, Volodymyr (2018), "Method for Determination of Cyber Threats Based on Machine Learning for Real-Time Information System", International Journal of Intelligent Systems and Applications, vol. 10, no. 8, pp. 11-18. DOI: $10.5815 /$ ijisa.2018.08.02

[3] Kovalchuk, T.I. Korystin, O.Y. and Sviridyuk, N.P. (2019), "Hybrid threats in the civil security sector in Ukraine", Problems of Legality, vol. 147, pp. 163-175, DOI: $10.21564 / 2414-990 x .147 .180550$

[4] Bashir, Eman and Bouguessa, Mohamed (2021), "Data Mining for Cyberbullying and Harassment Detection in Arabic Texts", International Journal of Information Technology and Computer Science, vol. 13, no. 5, pp. 41-50. DOI: $10.5815 /$ ijitcs.2021.05.04

[5] Frederick F. Patacsil (2019), "Analysis of Cyberbullying Incidence among Filipina Victims: A Pattern Recognition using Association Rule Extraction", International Journal of Intelligent Systems and Applications, vol. 11, no. 11, pp. 4857. DOI: 10.5815/ijisa.2019.11.05

[6] General comment No. 25 on children's rights in relation to the digital environment (2021), available at:

https://docstore.ohchr.org/SelfServices/FilesHandl er.ashx?enc $=6 \mathrm{QkG1d} \% 2$ FPPRiCAqhKb7yhsqIkir KQZLK2M58RF\%2F5F0vEG\%2BcAAx34gC78F wvnmZXGFU19nJBDpKR1dfKekJxW2w9nNryR sgArkTJgKelqeZwK9WXzMkZRZd37nLN1bFc2t

[7] Recommendation CM/Rec 7 of the Committee of Ministers to member States on Guidelines to respect, protect and fulfil the rights of the child in the digital environment (2018), available at: https://violenceagainstchildren.un.org/sites/violenc eagainstchildren.un.org/files/documents/political_ declarations/recomendation_of_the_committee_of _ministers_of_the_council_of_europe_to_member _states_on_guidelines_to_respect_protect_and_ful fil_the_rights_of_the_child_in_the_digital_enviro nment.pdf (date of access: 09.10.2021).

[8] Wenge, J.M. Martin, G.N. and Campbell, W.K. (2018), "Decreases in psychological well-being among American adolescents after 2012 and links to screen time during the rise of smartphone technology", Emotion, vol. 18 (6), pp. 765-780, available at: https://doi.org/10.1037/emo0000403

[9] Sherly, T.T. and Dr B. Rosiline Jeetha (2021), "A survey on cyberbullying detection", IEEE International Confrence on Advances in Computer Applications, available at: https://www.researchgate.net/publication/3541769 31_A_SURVEY_ON_CYBERBULLYING_DET ECTION

[10] Hinduja, S. and Patchin, J.W. (2014), Bullying Beyond the Schoolyard: Preventing and Responding to Cyberbullying. Corwin; Second edition.

[11] Willard, N.E. (2007), Cyberbullying and cyberthreats: Responding to the challenge of online social aggression, threats, and distress, 2nd edition. Champaign, IL: Research Publisher LLC.

[12] Kowalski, R.M. Limber, S.P. and Agatston, P.W. (2012), Cyberbullying: Bullying in the digital age (2nd ed.), Malden, MA: Wiley-Blackwell.

[13] Chalfen, R. (2009), "It's only a picture: Sexting, "smutty" snapshots and felony charges", Visual Studies, vol. 24 (3), pp. 258-268, available at: https://doi.org/10.1080/14725860903309203

[14] Bielčiková, K. (2021), "The relationship between cyberbullying and sexting", 13th International Conference on Education and New Learning Technologies. DOI: 10.21125/edulearn.2021.0130

[15] Al-Alosi, H. "Cyber-violence: digital abuse in the context of domestic violence", UNSW Law Journal, vol. 40 (4), pp. 1573-1603.

[16] Agus, M. Mascia, M.L. Zanetti, M.A. Perrone, S. Rollo, D. and Penna, M.P. (2021), "Who Are the Victims of Cyberbullying? Preliminary Data Towards Validation of "Cyberbullying Victim Questionnaire", Contemporary Educational Technology, vol. 13 (3), available at: https://doi.org/10.30935/cedtech/10888

[17] Extremera, N. Quintana-Orts, C. MéridaLópez, S. and Rey, L. (2018), "Cyberbullying Victimization, Self-Esteem and Suicidal Ideation in Adolescence: Does Emotional Intelligence Play a Buffering Role?", Front. Psychol, vol. 9, pp. 367. DOI:10.3389/fpsyg.2018.00367

[18] Code of Ukraine on Administrative Offenses of 07.12.1984 No. 8073-X, available at: https://zakon.rada.gov.ua/laws/show/80731-10

[19] Korystin, O.Ye. and Sobko, H.M. (2019), "Methodological principles of understanding the phenomenon of "violence" in criminal law", Nauka i Pravookhorona, no. 2 (44), pp. 139-148, DOI: 10.36486/np.2019.2 
[20] National Strategy on Human Rights: Decree of the President of Ukraine of 24.03.2021 No. 119/2021, available at: https://www.president.gov.ua /documents/1192021-37537

[21] National Strategy for Reforming the Justice System for Children for the period up to 2023: Regulation of the Cabinet of Ministries of Ukraine No. 1027-r. from 18.12.2018, available at: https://zakon.rada.gov.ua/laws/show/1027-2018$\% \mathrm{D} 1 \% 80 \#$ Text

[22] State Social Program "National Plan for the Implementation of the UN Convention on the Rights of the Child" for the period up 2021: Resolution of the Cabinet of Ministries of Ukraine of 30.05.2018 No. 453, available at: https://zakon.rada.gov.ua/laws/show/453-2018$\% \mathrm{D} 0 \% \mathrm{BF} \# \mathrm{n} 10$ 